Nadwa : Jurnal Pendidikan Islam

Vol. 12, Nomor 2 Tahun 2018

Accredited by Ristekdikti based on Decree No. 51/E/KPT/2017

\title{
The Cultivation of Tolerance Value in Madrasah through Tahfidh Hadits
}

\author{
Ahmad Musyafiq \\ UIN Walisongo, Semarang, Indonesia \\ ahmad_musyafiq@walisongo.ac.id
}

\begin{abstract}
This article will analyze the content and learning process of the tahfidh hadith in Integrated Madrasah Ibtidaiyah (MIT) Nurul Islam Ngaliyan Semarang related to the cultivation of tolerance values. This study uses content analysis and in-depth interviews. The results of this study are that first, most of the contents of the tahfid hadith package contain ghairu mahdlah (social) worship which reaches $83 \%$, in which there is a tolerance value, while the hadith about worship is $17 \%$. Second, the tahfidh learning process uses a variety of methods, namely writing, reading, memorizing, translating and monitoring the application of the values contained in the hadith in everyday life.
\end{abstract}

Keywords: cultivation; tolerance value; tahfidh hadith, madrasah;

\begin{abstract}
Abstrak
Artikel ini akan menganalisa isi dan proses pembelajaran tahfidh hadis di Madrasah Ibtidaiyah Terpadu (MIT) Nurul Islam Ngaliyan Semarang terkait dengan penanaman nilai-nilai toleransi. Penelitian ini menggunakan analisis isi dan wawancara mendalam. Hasil penelitian menunjukkan bahwa pertama, sebagian besar isi paket hadis tahfidh memuat ibadah ghairu mahdlah (sosial) yang mencapai $83 \%$, yang di dalamnya terdapat nilai toleransi, sedangkan hadits tentang ibadah mahdhah $17 \%$. Kedua, Proses pembelajaran tahfidh hadis menggunakan berbagai variasi metode yaitu menulis, membaca, menghafal, menerjemah dan pemantauan penerapan nilai-nilai yang terkandung dalam hadits dalam kehidupan sehari-hari .
\end{abstract}

Kata Kunci: penanaman; nilai toleransi; tahfidh hadis; madrasah;

IS SN 1979-1739 (P) ; ISSN 2502-8057 (E).

G 2018 Nadwa : Jurnal Pendidikan Islam / UIN Walis ongo.

Accredited by Ristekdikti based on Decree No 51/E/KPT/2017

http:/joumal.wal isongo.ac.id/index.php'nadwa 


\section{Introduction}

The emergence of radical actions is partly due to the low appreciation for tolerance value, namely the attitude of tolerating: respecting, letting, allowing the attitude in the form of opinions, views, beliefs, habits and others that are different and or contrary to his or her attitude.1 Efforts to instill awareness of the value of tolerance are the responsibility of all elements, including the world of education. Mentioned in the Republic of Indonesia Law Number 20 of 2003, that: "National education aims to develop the potential of students to become believers and fear of God Almighty, noble, healthy, knowledgeable, capable, creative, independent, and become a democratic and responsible citizen." This goal cannot be realized in a short time, but in a long period of time, covering all levels of education, including in madrasas.

There are a number of reasons for the importance of cultivation of a tolerance value through the tahfidh hadith at the basic education level. First, the Hadith has a very central position in the structure of the source of Islamic teachings. It is the second source after the Quran. Even the Quran cannot be understood and practiced properly and correctly without the description of the Hadith. Second, memorization is one of the learning techniques that will have a very long impact, especially if done in childhood.2 Because what is memorized is the material of hadith, then this material will be embedded very strongly in the hearts of students.

One of the schools that has tahfidh hadith subjects is MIT (Integrated Islamic Madrasa) Nurul Islam Ngaliyan Semarang. This school is one of Islamic elementary school that has special characteristics. Its specialty can be seen from the doubled Islamic content. It is said to be doubled because of the two elements, namely its status as "Madrasah Ibtidaiyah" and "Integrated."

1 Imam Tholkhah, "Pendidikan Toleransi Keagamaan: Studi Kasus SMA Muhammadiyah Kupang Nusa Tenggara Timur," Edukasi 11, no. 2 (2013): 165-81.

2 Qurrotul Aini, "Penerapan Metode Tahfidz Untuk Meningkatkan Kemampuan Siswa Pada Mata Pelajaran Al-Qur'an Hadist Di MTsN Ngantru Tulungagung" (IAIN Tulungagung, 2017), http://repo.iaintulungagung.ac.id/id/eprint/6274. 
The Integrated term in education was originally related to the term Integrated Islam. In Elementary Schools, the term used is Integrated Islam Elementary School (SDIT), while in the Madrasah Ibtidaiyah the term used is Integrated Islamic Junior High School (MIT) to avoid unnecessary repetition (pleonasme). Schools like this were initially spearheaded by schools managed by mass organizations with transnational ideology, as part of the Global Salafism movement in Indonesia.3 This characteristic is intended as an effort to equip a more militant Islamic spirit. But in its development, the militancy sometimes has a negative impact in the form of reduced spirit of tolerance, because of the homogeneity of students in terms of religion. On the other hand, MIT Nurul Islam is in the environment of and has been affiliated with traditional and moderate mass organizations.

\section{Tahfidh hadith at MIT Nurul Islam Ngaliyan Semarang}

1. Overview of MIT Nurul Islam

Broadly speaking, there are two types of basic education. The first is elementary school (SD). That is a school whose curriculum follows the curriculum of the Ministry of Education and Culture. Most subjects are non-religious. While the religious lessons are only a small portion. Generally this type of school is attended by students with different religious backgrounds. So that they have become accustomed to the diversity of religious followers since their children. They are familiar with a pluralistic environment. This plurality spirit is very important for the formation of students' character related to the cultivation of tolerance values.

The second is schools that are under the auspices of the Ministry of Religion. One of them is Madrasah Ibtidaiyah. This term is actually an Arabic term that means elementary school. But, maybe because it is an Arabic term, MI has a narrowing of meaning, namely the type of elementary school that has Islamic characteristics, both in terms of managers, curriculum and students. The percentage of religious subjects is more than that in elementary schools.

3 Ubaidillah Ubaidillah, "Global Salafism Dan Pengaruhnya Di Indonesia," Thaqafiyyat 13, no. 1 (2012): 35-48. 
Regarding the Integrated term that accompanied this MI, it was found that the start was around 2004. One of the school administrators found that there were more advanced schools with integrated characteristics. 4 The meaning of integrated includes at least four things. First, integration between school and parents. This is important so that what is taught at school is maintained when students are at home with family. Second, integration between school and community. It is also important that what is taught in schools is not contaminated by what is happening in the community. Third, integration in the curriculum, both among subjects and between non-religious subjects and religious ones. Fourth, this is more specific, the integration between science and practice, especially related to religious aspects. At this school, religious practice is very emphasized, especially prayer in congregation. For example, when a meeting was taking place, then there was a call to prayer, so the meeting had to be stopped and everyone had to come to the mosque to congregate.

In addition to strong Islamic characteristics, like the Islamic Madrasah in general, MIT Nurul Islam is inseparable from the potential for reducing the cultivation of a plurality spirit. This potential is very counterproductive to the task of educational institutions related to the cultivation of national values. Therefore, comprehensive handling is needed, including through the subjects given.

Judging from the socio-religious background, the students and parents of the Madrasah Ibtidaiyah are all Muslims with diverse backgrounds in religious organizations, ranging from traditional, modern to puritanical ones. This heterogeneity on the one hand can increase the spirit of tolerance, but still be internally among Muslims. On the other hand, these Madrasas are located in areas where citizens have a very high level of plurality, including social and religious issues and are struggling with modernity in various fields.

This diversity of communities around Madrasas has two effects at once. First, related to the integration between school and community, the diversity of society can have a less positive impact. The students will be faced with many things that are

4 Wawancara dengan Waka Kurikulum, Jumaidi, Kamis 16 Agustus 2018 
different from what is taught in school. For example, related to the discipline of the implementation of worship, what happens in society can be the opposite of what is taught and practiced in school. Second, related to the cultivation of a spirit of tolerance, what happens in the community can have a positive impact. Because students interact directly with the reality of a society that is indeed plural. Therefore, it is necessary to deal proportionally with regard to the conditions of the community which can have two contradictory impacts.

\section{Tahfidh hadith Content}

Tahfidh hadith is a certain amount of Hadith memorization. Hadith is everything that is based on the Prophet Muhammad in the form of words, taqrir 5 and physical and non-physical characters and sirah, both before and after being appointed as rasul.6 As the name suggests, the basic competency is the ability to memorize. Although memorizing is at the lowest level, but because it is within the framework of other competencies, it also has a very important role.7

At MIT Nurul Islam Ngaliyan Semarang tahfidh hadith was given to students from class 1 to class 5 , while class 6 was used to repeat. In total there are 50 short hadiths. 8 Each hadith is presented in its matan and is followed by the mukharrij (narrator who also records the hadith). 9 Presentation models like this are

5 Taqrir dalam definisi Hadis umumnya diterjemahkan dengan "ketetapan". Tetapi perlu digarisbawahi bahwa makna taqrir tidak sama dengan "ketetapan" dalam Bahasa Indonesia. Taqrir adalah pengakuan Nabi saw terhadap yang apa beliau lihat atau beliau dengar dilakukan oleh sahabat. Karena itu, lebih tepat kalau istilah taqrir tidak diterjemahkan, tetapi diberi penjelasan. Bila terpaksa diterjemahkan, agaknya yang lebih tepat adalah "pengakuan", bukan "ketetapan".

6 M. Ajjaj Al-Khathib, Ushul Al-Hadis: Pokok-Pokok Ilmu Hadis, ed. Muhammad Qodirun Nur and Ahmad Musyafiq, 5th ed. (Jakarta: Gaya Media Pratama, 2013).

7 Aini, "Penerapan Metode Tahfidz Untuk Meningkatkan Kemampuan Siswa Pada Mata Pelajaran Al-Qur'an Hadist Di MTsN Ngantru Tulungagung."

8 Tim Penyusun, Panduan Praktis Hafalan Hadis Dan Doa (Semarang: MIT Nurul Islam, n.d.).

9 Syuhudi Ismail, Metodologi Penelitian Hadis, 2nd ed. (Jakarta: Bulan Bintang, 2008). 
enough. But it would be better if at least added the narrator at the level of companions (sahabat), or the reference from the original book was included. In other words, the presentation of tahfidh content like this still requires takhrij effort (tracking the hadith to the original source). 10 Maybe because the level is still in elementary school, this kind of presentation is considered enough.

Broadly speaking, this tahfidh content can be classified into three, namely the dominant hadiths related to mahdhah worship, the dominant hadiths related to ghair mahdhah worship and the traditions related to both at once. What is meant by mahdhah worship here is worship in which the procedure is determined by the Shari'a. More specifically, mahdlah worship is a service which is a constituent of the pillars of Islam, such as syahadat, prayer, zakat, fasting and Hajj. Besides being ritualistic, this type of worship has been determined by the procedure of the Shari'a. So that innovating this type of worship will be included in the category of prohibited bid'ah. While ghairu mahdhah worship is worship whose procedure is not ritualistic and not specifically determined by the Shari'a. Therefore, it is possible to innovate in its implementation. What does not change (al-tsabit) is the substance, while the implementation, even its form can change along with changes in time and place (yataghayyar bi taghayyur al-azminah wa al-amkinah).

Of the fifty hadiths spread in five classes, the hadiths relating to mahdlah worship have 6 hadiths (12\%), which are related to ghair mahdlah worship there are 39 hadiths (78\%) and those related to both had 5 hadiths $(10 \%)$. The hadiths related to ghair mahdlah worship can still be classified into individual services, social services and both at the same time. The individual meaning is the hadith whose material is related to each individual. Whereas the social one is the hadith whose contents are not only related to the individual's self, but also related to his interaction with others. Of the 39 hadiths related to the ghair mahdlah worship, there are $4(10.26 \%)$ which are individual, there are $26(66.67 \%)$ which are social and $9(23.07 \%)$ the remnant are both at once. Details of the themes and classifications of the tahfidh hadith content at MIT Nurul Islam Ngaliyan can be seen in the following table: 


\section{Table:}

\section{Tahfidh Hadith Content at MIT Nurul Islam} Ngaliyan Semarang

\begin{tabular}{|c|c|c|c|c|c|c|}
\hline \multicolumn{2}{|c|}{ NO } & CLS & SMT & THEMES & $\begin{array}{l}\text { M/GM/ } \\
\text { M-GM }\end{array}$ & $\begin{array}{l}\mathbf{I} / \mathbf{S} / \\
\mathbf{I}-\mathbf{S}\end{array}$ \\
\hline 1 & 1 & 1 & 1 & Cleanliness & GM & $\mathrm{S}$ \\
\hline 2 & 2 & & & Affection & GM & $\mathrm{S}$ \\
\hline 3 & 3 & & & Salat & $\mathrm{M}$ & \\
\hline 4 & 4 & & & Brotherhood (1) & GM & $\mathrm{S}$ \\
\hline 5 & 5 & & & Angry Ban & GM & $\mathrm{I}-\mathrm{S}$ \\
\hline 6 & 6 & & & Kindness (Alms 1) & GM & $\mathrm{S}$ \\
\hline 7 & 1 & & 2 & Shame & GM & $\mathrm{I}-\mathrm{S}$ \\
\hline 8 & 2 & & & Spread Greetings & GM & $\mathrm{S}$ \\
\hline 9 & 3 & & & $\begin{array}{l}\text { Traits (Morals) of the } \\
\text { Prophet }\end{array}$ & GM & $\mathrm{S}$ \\
\hline 10 & 4 & & & Smile & GM & $\mathrm{S}$ \\
\hline 11 & 5 & & & Religion is Advice & GM & I \\
\hline 12 & 1 & 2 & 1 & Eating Habits & GM & I \\
\hline 13 & 2 & & & Good Words & GM & $\mathrm{S}$ \\
\hline 14 & 3 & & & Studying & GM & I \\
\hline 15 & 4 & & & $\begin{array}{l}\text { Learning (and } \\
\text { Teaching) the Quran }\end{array}$ & M-GM & \\
\hline 16 & 5 & & & $\begin{array}{l}\text { Faith and } \\
\text { Characteristics }\end{array}$ & GM & $S$ \\
\hline 17 & 6 & & & $\begin{array}{l}\text { Obligation to be } \\
\text { Grateful (and thankful) }\end{array}$ & GM & I-S \\
\hline 18 & 1 & & 2 & $\begin{array}{l}\text { Advanced Reading of } \\
\text { the Quran }\end{array}$ & M-GM & \\
\hline 19 & 2 & & & $\begin{array}{l}\text { Prayers in } \\
\text { Congregation }\end{array}$ & M & \\
\hline 20 & 3 & & & Brotherhood (2) & GM & $\mathrm{S}$ \\
\hline 21 & 4 & & & $\begin{array}{l}\text { Ridla Allah with } \\
\text { Parents }\end{array}$ & GM & $\mathrm{S}$ \\
\hline 22 & 5 & & & $\begin{array}{l}\text { Prayers, Alms (2) and } \\
\text { Patience }\end{array}$ & M-GM & \\
\hline 23 & 1 & 3 & 1 & Heaven's Key & GM & $\mathrm{S}$ \\
\hline 24 & 2 & & & Friday prayer & $\mathrm{M}$ & \\
\hline 25 & 3 & & & Ramadan fasting & M & \\
\hline 26 & 4 & & & Intention & M-GM & \\
\hline 27 & 1 & & 2 & Silaturrahim & GM & $\mathrm{S}$ \\
\hline 28 & 2 & & & Respecting Guests & GM & $\mathrm{S}$ \\
\hline
\end{tabular}




\begin{tabular}{|c|c|c|c|c|c|c|}
\hline 29 & 3 & & & Showing Goodness & GM & $\mathrm{S}$ \\
\hline 30 & 4 & & & Islam is High & GM & $\mathrm{I}$ \\
\hline 31 & 5 & & & $\begin{array}{l}\text { Prohibition of } \\
\text { Reproach }\end{array}$ & GM & $\mathrm{S}$ \\
\hline 32 & 1 & 4 & 1 & $\begin{array}{l}\text { Perfection of Faith } \\
\text { (Loving Others) }\end{array}$ & GM & $\mathrm{S}$ \\
\hline 33 & 2 & & & Respecting the Older & GM & $\mathrm{S}$ \\
\hline 34 & 3 & & & Loving Orphans & GM & $\mathrm{S}$ \\
\hline 35 & 4 & & & $\begin{array}{l}\text { Prohibition of Talking } \\
\text { about All that was } \\
\text { Heard }\end{array}$ & GM & I-S \\
\hline 36 & 5 & & & $\begin{array}{l}\text { Prohibition of Hating } \\
\text { (Silencing Others) }\end{array}$ & GM & I-S \\
\hline 37 & 1 & & 2 & $\begin{array}{l}\text { Takwa (and } \\
\text { Characteristics) }\end{array}$ & GM & I-S \\
\hline 38 & 2 & & & $\begin{array}{l}\text { Signs of Munafiq } \\
\text { People }\end{array}$ & GM & I-S \\
\hline 39 & 3 & & & Ban of Lies & GM & I-S \\
\hline 40 & 4 & & & $\begin{array}{l}\text { Loving Whom on Earth } \\
\text { (the Same Creatures) }\end{array}$ & GM & $\mathrm{S}$ \\
\hline 41 & 1 & 5 & 1 & Telling the Truth & GM & $\mathrm{S}$ \\
\hline 42 & 2 & & & Virtue of Giving & GM & $\mathrm{S}$ \\
\hline 43 & 3 & & & $\begin{array}{l}\text { Good Deed (Childly } \\
\text { Righteous) }\end{array}$ & GM & I-S \\
\hline 44 & 4 & & & Whispering Ban & GM & $\mathrm{S}$ \\
\hline 45 & 5 & & & $\begin{array}{l}\text { Fasting Becomes } \\
\text { Intercession }\end{array}$ & $\mathrm{M}$ & \\
\hline 46 & 1 & & 2 & How to Greet & M-GM & \\
\hline 47 & 2 & & & $\begin{array}{l}\text { Prohibition of Taking } \\
\text { Other People's Items }\end{array}$ & GM & $\mathrm{S}$ \\
\hline 48 & 3 & & & Shake Hands & GM & $\mathrm{S}$ \\
\hline 49 & 4 & & & $\begin{array}{l}\text { Muslim Rights } \\
\text { (Obligations) to Other } \\
\text { Muslims }\end{array}$ & GM & $\mathrm{S}$ \\
\hline 50 & 5 & & & Pillars of Islam & $\mathrm{M}$ & \\
\hline
\end{tabular}

Note:

M (Mahdlah), GM (Ghairu Mahdlah), M-GM (Mahdlah and Ghairu Mahdlah at Once), I (Individual), S (Social) and I-S (Individual and Social at Once)

There are several other notes related to the content of this tahfidh hadith. First, in terms of giving titles. In the study of Hadith, the granting of titles is called al-tarjamah. So in the standard hadith books found the term tarjamah al-bab, the 
meaning is the provision of chapter titles.11 This lecture was carried out by the last narrator who also recorded the hadith into the book, which is technically called mukharrij. This effort is part of ijtihad carried out by Mukharrij. Because giving the title of a hadith is the same as giving the core meaning of that hadith.

Therefore, the books of standard hadith besides being seen as a source of law, can also be seen as a book of Fiqh. Because the title of one or a number of hadiths is the same as giving legal meaning. For this reason, the mukharrij by some people are also seen as Fuqaha at once, not merely as Muhaddisin. Even though in practice, most of the Muhaddisin became Fuqaha in a limited sense, because they were generally still within the framework of a particular school (madzhab). In other words, their ijtihad qualification are muqayyad, not muthlaq or often referred to as the mujtahid madzhab, not the mujtahid mustaqil.12

In practice, one hadith can be given more than one title. Because the contents are more than one. This is what underlies the repetition of hadith. So that the repetition of hadith in the hadith books is actually not ordinary repetition, because each is seen in terms of its different meanings. This results in the calculation of hadith, which is generally associated with the number of hadith with or without counting repetitions. For example the number of hadith in Sahih al-Bukhari without counting repetitions is four thousands, while with counting repetitions is seven thousand.13 So there are about three thousand repeated hadiths.

In the tahfidh hadith handbook of MIT Nurul Islam Ngaliyan, the title for each hadith is inaccurate and some are unclear. Both can be seen in the titles of themes that get additional words in parentheses. For example, written in the book of tahfidh the title for a hadith is "good" (Hadith number 6 from the content of tahfidh hadith class 1 semester 1). This title is not clear, so it is given by an addition in brackets with "alms". It means that the

11 Muhammad ibn Ismail Al-Bukhari, Al-Jami' Al-Shahih, ed. al-Sindiy (Beirut: Dar al-Fikr, 1995).

12 Abdul Wahhab Khallaf, Ilm Ushul Al-Fiqh, 2nd ed. (Beirut: Dar alHaramain, 2004).

13 Nuruddin Itr, Manhaj Al-Naqd Fi Ulum Al-Hadis, 29th ed. (Lebanon Beirut: Dar al-Fikr, 2008). 
translation of "goodness" is too broad, even though the contents of the hadith are about alms, it will be clearer if the title is alms. While the number one is added to explain that there are more than one number of hadiths related to the same theme. Another example is a hadith entitled "perfection of faith" (hadith number 1 of the class 4 semester 1). This title is too general. Because the content of hadith is about loving others, it will be clearer if the title is to love others. And so on, as can be seen in the table above.

Second, in terms of translation. Translating hadith is not easy. Because it is not enough to be done only by looking at the meaning of the word in the dictionary or its lexic meaning, but also the terminological meaning of the word. Because of that, to be able to translate properly and correctly, it is necessary to read a number of literatures, especially the books of syarah hadith. The reading of the syarah hadith books is important for several reasons. First, in those books, it can be found the meaning of each difficult word (al-mufradat) both in terms of lexic and terminology. Second, in those books also found a description based on related scientific fields, not even often accompanied by a variety of opinions of scholars in the field.

Translating hadith requires adequate mastery of the hadith scholarship and some sciences mentioned in the hadith being translated. Therefore, translation works are also seen as scientific work. Even in its history, translation plays an important role in the process of transfer of knowledge, as experienced by the Islamic world when translating Greek works into Arabic.

In the handbook of tahfidh the MIT Hadith Nurul Islam also found some incorrect translations. For example, the hadith of virtue of giving (hadith number 2 from the content of tahfidh hadith class 5 semester 1), the translation is written: "The hand above (the person who gives) is more important than the hand under (the person who receives)." (Narrated by al-Bukhari ) Explanation of the hands under with "the person receiving" is not appropriate. Because based on the explanation of the ulama in the books of syarah, for example in the Book of Dalil al-Falihin Syarah Riyadlus Salihin, it is stated that the meaning is the person 
who asks.14 Obviously different between "people who receive" and "people who ask". Receiving contains a positive impression. Even the person who receives can have the same position as the person who gives, because there can be no one who can give without anyone willing to accept. Because of that there is a suggestion that the person who gives also thanks the people who want to accept. While asking is for negative understanding.

\section{Tahfidh hadith Learning Process}

Tahfidh hadith learning is done by each class teacher. Therefore there are many variations in the process, as many as class teachers. However, the variation is only related to the style of each teacher. Because there are general rules that must be followed by each class teacher in assisting the learning of tahfidh hadith.

Tahfidh hadith learning begins with writing, reading, both Arabic and the translation, followed by memorizing together and ending with depositing memorization.15 At the writing stage, the teacher writes a hadith and translation on the blackboard, then each student writes in their respective notebooks. This is intended so that each student before memorizing has the ability to write and in the process of writing it also actually began to have hadith cultivation and its meaning in mind. Writing is also a tool to strengthen the psychomotor of each student.

At the reading stage, the teacher asks students to listen to the hadith text. The teacher then read the hadith several times, both Arabic and the translation. Then the teacher asks some students to read, to ensure that all students have been able to read the hadith properly. The quantity and quality of this stage are closely related to the level of the class. The higher the class level, the less quantity and quality of reading. This is reasonable, because the higher the grade level, the higher the level of reading ability.

Then at the memorization stage, the teacher monitors so that each child memorizes. The slow pace of memorizing children varies greatly, depending on the level of intelligence. In addition, the activeness of the child to murajaah (repeating) is also very

14 Muhammad bin 'Allan Al-Shiddiqi, Dalil Al-Falihin Syarh Riyadl AlShalihin, 1st ed. (Beirut: Dar al-Fikr, 2013).

15 Jumaidi 
decisive. The principle is that memorization is first done together in class. This will increase the enthusiasm of students. Then the teacher encourages students, including through parents so that in their homes they repeat and facilitate memorization. This stage is also part of an effort to practice integration between school and parents.

The last stage is the stage of depositing memorization by students to the class teacher. Deposits are made for memorized Hadith units. Usually the distance between memorizing with deposit is around two weeks. This stage is at the same time an evaluation stage. Therefore, whether or not the ability to memorize a child will determine its score. The results of this tahfidh assessment at the end of the semester will be an inseparable part of the report book received by each student.

\section{The Correlation of Tahfidh hadith with Cultivation of Tolerance Value}

By paying attention to the characteristics of hadith content as mentioned above, related to tahfidh correlation with the cultivation of tolerance value, it can be stated two things.

First, through tahfidh hadith content the students are invited to pay attention to the worship of ghair mahdhah. This is important in terms of instilling a more complete religious awareness. Religion is not only a matter of mahdlah worship, but also worship of ghair mahdhah. About mahdlah worship, students have been much convinced through Islamic subjects, such as Tauhid/Aqidah and Fiqh. So that the number of worshiporiented hadiths of Ghair Mahdlah can be a counterweight. This religious balance between mahdlah and ghair mahdlah worship is in turn expected to be a driving force for the birth of Muslims generation who are able to involve in society in various fields. This is one of the "integrated" meanings that accompany the name of this school. If so, this MI can also balance the puritanistic tendencies that accompany the integrated term on the one hand and traditionalism on the other. This combination of two tendencies is expected to be a factor for the strength of the nationalistic spirit. If it is associated with the value of tolerance, the hadiths which are categorized as ghair mahdlah do have a relationship, especially the ghair mahdlah traditions which are 
social. These types of hadiths are able to instill in students the importance of brotherhood and the importance of helping others. But if these values are not consciously and planned to be associated with a spirit of tolerance, they may be exclusive. Namely brotherhood and providing assistance only to same Muslims, considering all students are Muslim. Therefore, from this side, tahfidh hadith content does not directly have a relationship with the attenuation of tolerance values, which requires an attitude of respect for religious diversity. Tolerance and respect for diversity, including religious diversity, are important values to be cultivated early and fully. As the name of this school, cohesiveness also needs to be associated with nationalistic values which is the duty of every educational institution, including the Madrasah Ibtidaiyah.

Second, through the learning process of tahfidh hadith, by paying attention to the learning process of tahfidh as described above, there is almost no correlation with the cultivation of the tolerance value. Because most teachers do not include descriptions and explanations related to the hadith that will be memorized. The reason is because the subject is tahfidh, which linguistically means memorization. Most teachers choose to take a normative attitude, which is to adapt to the basic competencies of the content being taught. Memorization characteristics must be maintained properly, according to them, by not providing additional descriptions and explanations, because they will potentially disrupt the concentration of students. Indeed there are teachers who also include explanations on the sidelines of the tahfidh learning process, but the numbers are very small.16

The explanation is not necessarily related to the value of tolerance. This happens for several reasons. First, this tahfidh content is not designed to support the cultivation of tolerance values. Most teachers think that the value is sufficiently given through PPKn lessons. Even the cultivation of tolerance value has also been carried out through Islamic Cultural History (SKI) content, specifically related to the history of the State of Medina led by the Prophet Muhammad. The teacher can explain, how the Prophet Muhammad PBUH being very tolerant to people of 
different religions. 17 History relating to the life of the Prophet Muhammad PBUH terminologically known as Sirah. Sirah is a kind of science that talks about the life history of the Prophet Muhammad PBUH. This science has the same material object as the Hadith, but both are different in terms of formal objects. With regard to Hadith, this science has urgencies, one of them in terms of providing a broader context.18 So that by understanding Sirah well, it is hoped that one can understand the hadith well too. In other words, the hadith should be understood by including a broader context than what is found in Asbab al-Wurud. Apart from learning contents, the cultivation of tolerance values has also been carried out through various activities, such as commemoration of National Holidays, scouting, social services and similar activities. In contrast to other elementary schools, similar activities are quite a lot at MIT Nurul Islam Ngaliyan. This is what might also contribute to providing added value for the quality assurance of graduates from this school. Namely honed social intelligence of students, both in terms of the ability to interact with others, and in the sense of caring for those who are less fortunate. This is also the reason for some teachers not to need to give an explanation in the learning of tahfidh hadith. Secondly, the scientific background of teachers who do not always support the cultivation of tolerance values when associated with tahfidh hadith. Because of the fear of giving an explanation that is too far from the main purpose of the hadith being memorized, it will be safer without including an explanation. Providing explanations requires abilities that not all teachers have.

\section{Conclusion}

Based on the above explanation, some conclusions can be drawn. First, materially, most of the content of tahfidh hadith is indeed related to the worship of ghair mahdlah. But there are no hadith that explicitly lead to the cultivation of the tolerance value.

17 Jumaidi

18 Ahmad Musyafiq, Konteks Hadis: Telaah Metodologis Penggunaan Sirah Nabawiyah Dalam Pemahaman Hadis Nabawi, ed. Yayan Muhammad Royani and Nazar Nurdin, 1st ed. (Semarang, 2016). 
Even though the hadith occupies a very important position in the structure of the source of Islamic teachings. Memorizing Hadith is the same as memorizing one of the core sources of Islam. Thus, materially cultivating tolerance values on tahfidh Hadis content can be said to be quite low. Second, in terms of the learning process, there is no additional explanation relating to the content of the ghair mahdlah hadith in order to lead to the value of tolerance. Hadiths and translations are only written, read, then the child is asked to memorize, and then their memorization must be deposited to the teacher. Therefore, in terms of the learning process there is also no attempt to cultivate the value of tolerance carried out consciously and planned.

Based on these findings, it is recommended that into the tahfidh content, hadiths which can explicitly lead to tolerance values need to be added. In addition, the teachers must also be equipped with an awareness of the importance of instilling this value of tolerance in students. In the learning process, it is expected that the teacher also provides an explanation of the contents of the hadith.

Indeed, efforts to instill this value of tolerance have been carried out through other subjects. But these efforts must also be carried out on the content of the tahfidh hadith, as an inseparable part of all efforts to cultivate the tolerance value. This is also an implementation of the meaning of cohesiveness attached to this school.

\section{Reference}

Aini, Qurrotul. "Penerapan Metode Tahfidz Untuk Meningkatkan Kemampuan Siswa Pada Mata Pelajaran Al-Qur'an Hadist Di MTsN Ngantru Tulungagung." IAIN Tulungagung, 2017. http://repo.iain-tulungagung.ac.id/id/eprint/6274.

Al-Bukhari, Muhammad ibn Ismail. Al-Jami' Al-Shahih. Edited by al-Sindiy. Beirut: Dar al-Fikr, 1995.

Al-Khathib, M. Ajjaj. Ushul Al-Hadis: Pokok-Pokok Ilmu Hadis. Edited by Muhammad Qodirun Nur and Ahmad Musyafiq. 5th ed. Jakarta: Gaya Media Pratama, 2013. 
Al-Shiddiqi, Muhammad bin 'Allan. Dalil Al-Falihin Syarh Riyadl Al-Shalihin. 1st ed. Beirut: Dar al-Fikr, 2013.

Ismail, Syuhudi. Metodologi Penelitian Hadis. 2nd ed. Jakarta: Bulan Bintang, 2008.

Itr, Nuruddin. Manhaj Al-Naqd Fi Ulum Al-Hadis. 29th ed. Lebanon Beirut: Dar al-Fikr, 2008.

Khallaf, Abdul Wahhab. Ilm Ushul Al-Fiqh. 2nd ed. Beirut: Dar al-Haramain, 2004.

Masykuri, Muh Irham. "Pembelajaran Tahfiz Hadis Siswa Kelas 1 MI Muhammadiyyah (Unggulan) Juwiring Klaten.” UIN Sunan Kalijaga, 2009.

Musyafiq, Ahmad. Konteks Hadis: Telaah Metodologis Penggunaan Sirah Nabawiyah Dalam Pemahaman Hadis Nabawi. Edited by Yayan Muhammad Royani and Nazar Nurdin. 1st ed. Semarang, 2016.

Penyusun, Tim. Panduan Praktis Hafalan Hadis Dan Doa. Semarang: MIT Nurul Islam, n.d.

Rawantina, Novitasari Iriane, and I Made Arsana. "Penanaman Nilai Nasionalisme Dan Patriotisme Untuk Mewujudkan Karakter Pada Mata Pelajaran Pendidikan Kewarganegaraan Siswa Kelas X SMA Negeri 4 Sidoarjo.” Kajian Moral Dan Kewrganegaraan 1, no. 1 (2013): 39-54.

Ubaidillah, Ubaidillah. "Global Salafism Dan Pengaruhnya Di Indonesia.” Thaqafiyyat 13, no. 1 (2012): 35-48.

Ullyfaturrofi'ah, Ruska. "Integrasi Pendidikan Karakter Dengan Pembelajaran Mata Pelajaran Al-Qur' an Hadis Di Madrasah Aliyah Negeri Jombang.” UIN Sunan Ampel, 2017.

Yani, Ahmad. "Menakar Kurikulum Geografi 2013 Dalam Pengembangan Nilai Patriotisme." Mimbar 31, no. 2 (2015): 379-88. 